Original Research Paper

\title{
Effect of Cocoa Pod Husk Compost Produced Using Rot Fungi on the Growth of Cocoa Seedlings
}

\author{
${ }^{1}$ Laode Asrul, ${ }^{2}$ Iradhatullah Rahim, ${ }^{3}$ Tutik Kuswinanti, ${ }^{4}$ Burhanuddin Rasyid and ${ }^{3}$ Andi Nasruddin \\ ${ }^{I}$ Department of Agronomy, Faculty of Agriculture, Hasanuddin University, Makassar, Indonesia \\ ${ }^{2}$ Faculty of Agriculture, Animal Husbandry and Fisheries, Muhammadiyah University, Parepare, Indonesia \\ ${ }^{3}$ Department of Plant Pests and Diseases, Faculty of Agriculture, Hasanuddin University, Makassar, Indonesia \\ ${ }^{4}$ Department of Soil Science, Faculty of Agriculture, Hasanuddin University, Makassar, Indonesia
}

\author{
Article history \\ Received: 19-11-2017 \\ Revised: $25-11-2017$ \\ Accepted: 03-02-2018 \\ Corresponding Author: \\ Andi Nasruddin \\ Department of Plant Pests and \\ Diseases, Faculty of \\ Agriculture, Hasanuddin \\ University, Makassar, \\ Indonesia \\ Email: andinasruddin@yahoo.com
}

\begin{abstract}
Rot fungi have the ability to decompose organic materials into simple compounds or elements as nutrients for plants. In the process, rot fungi produce secondary metabolites and absorb phosphate from their substrates so that the phosphate become available to plants. The purpose of this study was to identify the species of rot fungi isolated from decaying cocoa stems and to determine the ability of the rot fungi insolubilizing phosphate and the effect of the husk compost on the growth of cocoa seedlings. The rot fungi were isolated and purified before they were grown on solid Pikovskaya's media amended with $0.5 \%$ tricalcium phosphate $\left(\mathrm{Ca}_{3} \mathrm{PO}_{4}\right)$ as a phosphate source. In addition, the effects of compost addition to growth medium (soil: compost $=2: 1$ ) on cocoa seedling growth was also determined. The results showed that there were eight species of rot fungi isolated from dead cocoa trees: Mycena sp., Lycoperdon sp., Auricularia sp., Schizoshyllum sp., Coprinus sp., Tremetes sp., Pleurotus sp. and Tremella sp. All isolates were capable of solubilizing phosphate from substrates but amongst all isolates, Lycoperdon sp. and Pleurotus sp. were the most effective in solubilizing phosphate, 3,198 and 3,094 $\mu \mathrm{g} \mathrm{L}^{-1}$, respectively. Effect of the compost produced using these two rot fungi on plant growth variables: the ratio of leaf area, plant dry weight, root canopy ratio and net assimilation rate, were comparable to chemical fertilizers. Thus, Lycoperdon sp. and Pleurotus sp. are promising decomposing agents for producing high quality compost made from cocoa pod husks as an alternative to inorganic fertilizers.
\end{abstract}

Keywords: Rot Fungi, Compost, Cocoa Pod Husks, Cocoa Seedling

\section{Introduction}

Cocoa pod husks can be used as a source of plant nutrients in the form of compost, animal feed, biogas production and the source of pectin. As an organic material, cocoa pod's skin contains nutrients and it is suitable to be used as a medium to grow plants. The water and organic matter contents of the cocoa husks are about 86 and 55.7\%, respectively (Soedarsono and Sulistyowati, 1997). Compost from the cocoa pod's skin has a $\mathrm{pH}$ of $5.4,1.30 \%$ of total $\mathrm{N}, 33.71 \%$ of organic $\mathrm{C}$, $0.186 \%$ of $\mathrm{P}_{2} \mathrm{O}_{5}, 5.5 \%$ of $\mathrm{K}_{2} \mathrm{O}, 0.23 \%$ of $\mathrm{CaO}$ and $0.59 \%$ of $\mathrm{MgO}$ (Sudirja et al., 2005). However, the nutrient contents can only be obtained through decomposition processes. White rot fungi have the ability to decompose a large amount of lignin with little loss of cellulose. The fungi secrete enzymes that degrade the organic materials into nutrients and change the lignocelluloses polymers into monomers that can more easily enter the root cells. Rot fungi secrete enzymes that degrade lignin. Degradation of lignin and cellulose contained in pod husks can reach 41.76 and $52.90 \%$, respectively after being incubated for 30 days with oyster mushrooms combined with Trichoderma sp. and rot fungal isolates (Kuswinanti et al., 2014).

Decomposed cocoa husks that are returned to cocoa plantation provide nutrient sources for the plants and sustain soil fertility (Ofori-Frimpong et al., 2010). 
Organic matters are natural substrates of saprophytic microorganisms and the organic matters indirectly provide nutrients for plants through the microbe activities. During decomposition process, organic acids such as humic and fulvic acids and growth hormones such as indole acetic acid (IAA), Gibberellic acid and cytokinin are released (Miezah et al., 2008).

Availability of $\mathrm{N}, \mathrm{P}$ and $\mathrm{K}$ nutrients to plants increases in the presence of humic and fulvic acids in the soil. Thus, the decomposing microbes help provide plants with available nutrients by producing the organic acids. In addition, the microbes can also directly provide available inorganic phosphate to plants through decomposition process (Rao, 2010). Therefore, the purposes of this study were to determine: (1) rot fungal species associated with decaying cocoa stems; (2) the ability of the rot fungi to dissolve phosphate from organic matters; and (3) the effect of cocoa husk compost produced using rot fungi on cocoa seedling growth.

\section{Materials and Methods}

\section{Isolation and Propagation of Fungi}

Isolates of rot fungi were obtained from decayed stems of cocoa plants in cocoa plantation in Bila Village, Sidrap District, South Sulawesi. The fruit bodies of the fungi were stored in paper bags and brought back to our laboratory for further process. Pieces of fungal fruit bodies $(1 \times 1 \mathrm{~cm}$ in size $)$ were surface sterilized with $70 \%$ alcohol, rinsed twice with sterile water and placed on to sterile filter paper. Each piece $(\phi 7 \mathrm{~mm})$ was grown aseptically on PDA medium and incubated at room temperature. After sub culturing and purification, isolates were then identified and labelled with the species of fungi.

\section{Ability to Dissolve Phosphate}

To determine the ability of the rot fungi in dissolving phosphate from organic matters, Pikovskaya's method was used (Rao and Sinha 1963). Isolates of the rot fungi were grown on solid Pikovskaya's media by using $0.5 \%$ tri-Calcium Phosphate $\left(\mathrm{Ca}_{3} \mathrm{PO}_{4}\right)$ as a phosphate source. Phosphate dissolving capability of the fungi is indicated by the formation of a clear zone around the isolates.

In order to quantify the phosphate dissolving capability of the fungi, the fungi were separately cultured on Pikovskaya's liquid medium and then shaken for 7 days. After that, the isolate suspension was filtered through Whatman filter paper no. 42 and then the filtrate was centrifuged for $15 \mathrm{~min}$ at a speed of $10,000 \mathrm{rpm}$. Five $\mathrm{mL}$ of the supernatant was put in a test tube and then added with $0.5 \mathrm{~mL}$ of highly concentrated reaction phosphate (112 g ammonium molybdate, $0.277 \mathrm{~g}$ calcium antimonyl tartrate), shaken for $5 \mathrm{~min}$ and then allowed to stand for $30 \mathrm{~min}$. The filtrate's $\mathrm{pH}$ level was determined and the absorbance was measured using a spectrophotometer with $\lambda=693 \mathrm{~nm}$. Titrisol standard curve $\left(\mathrm{PO}_{4}\right)$ was made of a dilution concentrations ranging from 0 to $2.5 \mathrm{mg} \mathrm{L}^{-1}$ with the regression equation of $\mathrm{Y}=0.191 \mathrm{x}+0.04, \mathrm{R}^{2}=0.957$. The concentration of the filtrate is determined by comparing the absorbance and the standard curve.

\section{Effect of Cocoa Husk Compost on the Growth of Cocoa Seedling}

A greenhouse experiments was conducted to determine the effect of cocoa pod husk compost on the growth of cocoa seedlings The experiment used a complete randomized block design with three treatments: Mixture of soil and cocoa husk compost made by using Lycoperdon sp., mixture of soil and cocoa husk compost made by using Pleurotus sp. and mixture of soil and inorganic NPK fertilizer. Each treatment had five replications of a polybag each. Seeds of cocoa cv. Sulawesi 2 were spread over a burlap bag and then the seeds were covered with another burlap bag. The bags were kept wet until the seed emerged and formed cotyledons. Growth medium were prepared by filling the polybags $(30 \times 40 \mathrm{~cm})$ with the soil and compost mixture $(2: 1)$ for each respective treatment. Two of the emerging seeds were planted in each polybag with about $1 \mathrm{~cm}$ depth.

\section{Data Collection}

The effect of cocoa pod husk compost on cocoa seedling growth was determined by measuring the following parameters (Gardner et al., 1985):

- Leaf Area Index (LAI), measure in 90 days after planted

LAI = Leaf area total/ plant area

- $\quad$ Net Assimilation Rate (NAR)

$\mathrm{NAR}=(\mathrm{W} 2-\mathrm{W} 1) /(\mathrm{T} 2-\mathrm{T} 1) \times(\ln \mathrm{ld} 2-\ln \operatorname{ld} 1) /(\mathrm{ld} 2-\mathrm{ld} 1)$.

- Crop Growth Rate (CGR):

$$
\begin{aligned}
& \overline{N L D}=\frac{1}{T 2-T 1} \int_{T 1}^{T 2} l d / w=\frac{l d 2-l d 1}{W 2-W 1} \\
& \times \frac{\ln W 2-\ln W 1}{l d 2-l d 1} \mathrm{~cm}^{2} / \mathrm{mg}
\end{aligned}
$$

Where:

$l d 1 \quad=$ Leaf area in first measurement (42 days)

$l d 2=$ Leaf area in the end of experiment (63 days)

$W 1 \quad=$ Total dry weight in the first measurement

$W 2=$ Total dry weight in the end of experiment

$T 1-T 2=$ Period of growth (21 days).

- Shoot/root ratio, calculated by dividing the shoot dry weight with root dry weight. 
The data were analyzed using analysis of variance (ANOVA). If the analysis showed a significant difference, then the treatment means were separated using Tukey's test $(\mathrm{P}=0.05)$.

\section{Results and Discussion}

\section{Rot Fungi Isolated from Cocoa}

All rot fungi isolated from rotten cocoa stems belonged to the Division of Basidiomycota. Basidiomycota has a large fruitbody that can be easily observed. The fruitbodies consist of a hood (pileus), blade (lamella) and stem (stipe). There were eight species of rot fungi isolated in this study, namely: (1) Mycena sp, a small, live in groups, with a rounded hood. Mycena is apolyphyletic genus in large numbers (Zhang et al., 2012); (2) Lycoperdon sp. is rot fungus with round fruit body hood with porous holes in the middle. This fungus is also known as puff ball mushroom (Bear and Rintoul, 2014); (3) Auricularia sp is a fungus that solitarily grows on the cocoa tree and without stalk attached to the bark of the cocoa plant. This fungus is white and the bottom of the hood with fine pores. The fruit bodies of Auricularia sp vary in shape and size (Webster and Weber, 2007); (4) Schizophyllum sp. is shaped like a fan, a little hairy and grey. This fungus is found in greater numbers than other rot fungi (Salahuddin, 2008); (5) Coprinus sp. has stems that can reach $8 \mathrm{~cm}$ long with a thickness of $4-8 \mathrm{~mm}$. Mature hood color is brown to black, some species are slightly pink (Keirle et al., 2004; Kuo, 2008); (6) Tremella sp. has fruit body with different colors, yellow, orange and brownish. Variation in fruit body color is due to the variation of carotenoid content and light intensity (Webster and Weber, 2007); (7) Trametes sp is saprobic on dead cocoa plant wood. The hood can reach $10 \mathrm{~cm}$, circular, semi-circular, or kidney-shaped, often fused with other hoods, densely hairy or velvety, with concentric zones of white, brown and reddish brown (Kuo, 2005); (8) Pleurotus sp. also known as oyster mushrooms. This fungus is cultivated because it tastes good and has a high nutritional value. It has the ability to kill nematodes with a known toxin named trans-2-decenedioic acid (Kwok et al., 1992) and linoleic acid (Webster and Weber, 2007).

\section{Ability of the Rot Fungi to Dissolve Phosphate}

All rot fungi isolated from decomposed cocoa plant have the ability to dissolve phosphate from tricalcium phosphate $\left(\mathrm{Ca}_{3} \mathrm{PO}_{4}\right)$, as indicated by the $\mathrm{P}$ content in the supernatant (Table 1). Lycoperdon sp. and Pleurotus sp. are the most effective amongst the fungi tested in dissolving phosphate.

The $\mathrm{pH}$ levels of the supernatants varied amongst the isolates, ranging from 5.25 to 6.04 , but lower than the control pH of 6.9 (Table 1). Thus, supernatant $\mathrm{pH}$ tended towards acidity creating suitable environment for the rot fungi to grow. For example, the optimal $\mathrm{pH}$ for the mycelial growth of Pleurotus spp. is 5.5-6.5 (Chang et al., 1993). In general, fungal spores on substrates tend to grow optimally at $\mathrm{pH}$ 4.5-7.0 (Chang et al., 1993). Optimum $\mathrm{pH}$ levels for the media vary amongst fungal strains and species (Vassilev et al., 1996). A decrease in $\mathrm{pH}$ in the liquid Pikovskaya's media is caused by organic acids produced by the fungus. Organic acids are very useful to increase the release of phosphates from the substrates. The higher the concentration of the organic acids, the higher the rate of phosphate absorption is (Rao, 2010).

In this study, the ability of the fungi to dissolve phosphate was quantitatively determined by measuring the supernatant absorbance using a spectrophotometer. The results showed that there were varying concentrations of phosphate solubilizing, ranging from 2036 to $3464 \mu \mathrm{g} \mathrm{L} \mathrm{L}^{-1}$. The highest concentration was found with Lycoperdon sp. isolates (Table 1). One way to improve the availability of phosphate in the soil is inoculating the seed or the soil with microorganisms as phosphate dissolver. Fungi are better phosphatedissolving agents than bacteria (Rao, 2010).

\section{Cocoa Seedling Growth}

Lycoperdon sp. and Pleurotus sp. produced the highest concentrations of dissolved phosphate compared to other fungal isolates tested (Table 1). Thus, the effect of the compost produced by the two fungi on cocoa seedling growth was determined in the greenhouse trial. The results of plant growth variable measurements are presented in Table 2.

Table 1: Solubilized phosphate content and supernatant $\mathrm{pH}$ of cocoa plant parts decomposed by different rot fungi

\begin{tabular}{lll}
\hline Ror Fungi & Supernatant $\mathrm{pH}$ & ${\text { Phosphate content }\left(\mu \mathrm{g} \mathrm{L} \mathrm{L}^{-1}\right)}$ \\
\hline Mycena sp. & 5.86 & 2.474 \\
Lycoperdon sp. & 5.69 & 3.198 \\
Auricularia sp. & 5.43 & 2.490 \\
Schizoshyllum sp. & 5.35 & 2.385 \\
Coprinus sp. & 5.55 & 2.977 \\
Tremetes sp. & 5.89 & 2.510 \\
Pleurotus sp. & 5.27 & 3.094 \\
Tremella sp. & 5.76 & 2.036 \\
\hline
\end{tabular}


Table 2: Growth variables of the cocoa seedlings planted in soil mixed with composts produced with rot fungi inoculation and inorganic fertilizers

\begin{tabular}{llll}
\hline & & Soil + compost with rot fungi \\
Growth Analysis & Soil + chemical fertilizer & Lycoperdon sp. & Pleurotus sp. \\
\hline Number of leaves (blades) & $6.89^{\mathrm{a}}$ & $6.11^{\mathrm{b}}$ & $6.22^{\mathrm{b}}$ \\
Leaf area $\left(\mathrm{cm}^{2}\right)$ & $46.75^{\mathrm{a}}$ & $43.97^{\mathrm{ab}}$ & $39.5^{\mathrm{b}}$ \\
Leaf area index & $0.96^{\mathrm{a}}$ & $0.93^{\mathrm{a}}$ & $0.86^{\mathrm{b}}$ \\
Leaf area ratio & $29.92^{\mathrm{a}}$ & $29.47^{\mathrm{a}}$ & $27.88^{\mathrm{a}}$ \\
Dry weight of plant $(\mathrm{g})$ & $1.53^{\mathrm{a}}$ & $1.56^{\mathrm{a}}$ & $1.35^{\mathrm{b}}$ \\
Root dry weight $(\mathrm{g})$ & $0.33^{\mathrm{a}}$ & $0.28^{\mathrm{a}}$ & $0.26^{\mathrm{a}}$ \\
Shoot/root ratio & $3.73^{\mathrm{b}}$ & $4.47^{\mathrm{a}}$ & $4.65^{\mathrm{a}}$ \\
CGR $\left(\mathrm{g} \cdot \mathrm{m}^{-2}\right.$ day $\left.^{-1}\right)$ & $0.69^{\mathrm{a}}$ & $0.57^{\mathrm{a}}$ & $0.39^{\mathrm{b}}$ \\
NAR $\left(\mathrm{g} \cdot \mathrm{m}^{-2}\right.$ day $\left.^{-1}\right)$ & $0.51^{\mathrm{a}}$ & $0.51^{\mathrm{a}}$ & $0.52^{\mathrm{a}}$ \\
\hline
\end{tabular}

The numbers followed by the same letter in the same row are not significantly different (Tukey's t test, $\mathrm{P}=0.05$ ). CGR $=$ crop growth rate; $\mathrm{NAR}=$ net assimilation rate.

For all plant growth parameters measured, cocoa husk compost produced using Lycoperdon sp. as decomposer was equally effective in promoting cocoa seedling growth as the inorganic fertilizer is, except for the number of leaves per seedling. For plants treated with cocoa husk compost produced using Pleurotus sp. had significantly lower number of leaves, leaf area, leaf area index and dry weight of plant but comparable in leaf area ratio, root dry weight, shoot/root ratio, CGR and NAR to inorganic fertilizer. This is in agreement with (Ofori-Frimpong et al., 2010) that cocoa pod compost are comparable to NPK (15:15:15) in supporting seedling growth.

\section{Conclusion}

There were eight species of rot fungi isolated from decayed cocoa trunks, namely: Mycena sp., Lycoperdon sp., Auricularia sp., Schizoshyllum sp., Coprinus sp., Tremetes sp. and Pleurotus sp. All fungal isolates were capable of solubilizing phosphate, but Pleurotus sp. and Lycoperdon sp. were the most effective. Cocoa pod husk compost produced using rot fungi were comparable with the inorganic fertilizer in promoting cocoa seedling growth. Thus, cocoa pod husks can be utilized as an organic fertilizer.

\section{Acknowledgement}

We would like to express our sincere appreciation to the Head of Research and Development of Plant Biotechnology, Hasanuddin University for laboratory facilities provided. We also thank Ahmad Yani for the technical assistance, Musakkar Tekeng and H. Anwar Sima (Pitu Riase Village, Sidrap Regency) for providing cocoa seedlings and pod husks.

\section{Funding Information}

The research was funded by the Institute of Research and Community Service, Hasanuddin University, Makassar, Indonesia.

\section{Authors' Contributions}

Laode Asrul: Coordinated research activities and critically revised the manuscript.

Iradhatullah Rahim: Designed research plan and organized data collection and analysis.

Tuti Kuswinanti: Designed research plan and performed data analysis.

Burhanuddin Rasyid: Design research plan and critically revising the manuscript.

Andi Nasruddin: Designed research plan, prepared the manuscript, critically revised the manuscript and acted as corresponding author.

\section{Ethics}

This article is an original research paper and contains unpublished data. All authors confirm that no ethical issues will occur due to the publication of this manuscript.

\section{References}

Bear, R. and D. Rintoul, 2014. Kingdom Fungi. Openstax-CNX module.

Chang, S.T., J.A. Buswell, P.G. Miles, 1993. Genetic and Breeding of Edible Mushrooms. 1st Edn., Gordon and Breach Science Publishers, Amsterdam.

Gardner, F.P., R.B. Pearce and R.L. Mitchel, 1985. Physiology of Crop Plants. 1st Edn., The Iowa State University Press, Ames, ISBN-10: 081381376X, pp: 327.

Keirle, M.R, D.E. Hemmes and D.E. Desjardin, 2004. Agaricales of the Hawaiian Islands. 8. Agaricaceae: Coprinus and Podaxis; Psathyrellaceae: Coprinopsis, Coprinellus and Parasola. Fungal Diversity, 15: 33-124.

Kuo, M., 2005. Trametes versicolor: The turkey tail. MushroomExpert.Com.

Kuo, M., 2008. Coprinoid mushrooms: The inky caps. Error! Hyperlink reference not valid. 
Kuswinanti, T., A. Rosmana, V.S. Dewi, Jamila, N. Hardina, 2014. Penggunaan isolat jamur dan bakteri pelapuk dalam dekomposisi limbah kulit kakao serta efektivitasnya dalam menghambat pertumbuhan patogen Phytopthora palmivora dan Lasiodipodia theobromae. Laporan penelitian (online). Jurusan Hama Dan Penyakit Tumbuhan, Fakultas Pertanian UNHAS, Makassar.

Kwok, O.C.H., R. Plattner, D. Weisleder and D.T. Wicklow, 1992. A nematicidal toxin from Pleurotus ostreatus NRRL 3526. J. Chem. Ecol., 18: 127-136. DOI: 10.1007/BF00993748

Miezah, K., J. Ofosu-Anim, G.K.O. Budu, L. Enu-Kwesi and O. Cofie, 2008. Isolation and Identification of Some Plant Growth Promoting Substances in Compost and Co-Compost. Int. J. Virol., 4: 30-40. DOI: $10.3923 /$ ijv.2008.30.40

Ofori-Frimpong, K., A.A. Afrifa and S. Acquaye, 2010. Relative efficacy of cocoa pod husk-based compost on growth and nutrient uptake of cocoa seedlings in the nursery. Ghana J. Agric. Sci., 43: 55-59.

Rao, S., 2010. Mikroorganisme tanah dan pertumbuhan tanaman. Penerbit UI Press. Jakarta.

Rao, S.and M.K. Sinha, 1963. Phosphate dissolving microorganisms in the soil and rhizosphere. Indian J. Agric. Sci., 33: 272-278.
Salahuddin, M.A.H., 2008. Biological activities of schizophyllum commune fr. Faculty of Science, University of Malaya, Kuala Lumpur.

Soedarsono, S.A. and E. Sulistyowati, 1997. Penebaran kulit buah kakao sebagai sumber bahan organik tanah dan pengaruhnya terhadap produksi kopi dan kakao. Pelita Perkebunan, 13: 90-99.

Sudirja, R., M.A. Solihin and S. Rosniawaty, 2005. Laporan penelitian pengaruh kompos kulit kakao dan kascing terhadap perbaikan beberapa sifat kimia fluventic eutrudepts. Universitas Padjadjaran, Bandung.

Vassilev, N., M. Fenice and F. Federici, 1996. Rock phosphate solubilization with gluconic acid produced by immobilized Penicillium variabile P16. Biotechnol. Technol., 10: 584-588. DOI: $10.1007 / \mathrm{BF} 00157366$

Webster, J. and R. Weber, 2007. Introduction to Fungi. 3rd Edition. Cambridge University Press, ISBN-10: 0521014832, pp: 867.

Zhang, L., J. Chen, L.V. Yali, C. Gao and S. Guo, 2012. Mycena sp., a mycorrhizal fungus of the orchid Dendrobium officinale. Mycol Progress, 11: 395-401. DOI: 10.1007/s11557-011-0754-1 